Check for updates

Cite this: RSC Adv., 2018, 8, 38047

Received 17th September 2018 Accepted 23rd October 2018

DOI: $10.1039 / c 8 r a 07650 b$

rsc.li/rsc-advances

\section{Preparation of a superfine RDX/Al composite as an energetic material by mechanical ball-milling method and the study of its thermal properties}

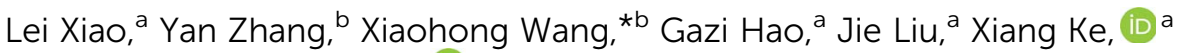 \\ Teng Chen ${ }^{a}$ and Wei Jiang (iD *a
}

\begin{abstract}
To research the influence of aluminum (Al) on the decomposition of 1,3,5-trimethylene trinitramine (RDX), a type of superfine RDX/Al composite as an energetic material with a mass ratio of 70/30 was successfully prepared by mechanical ball-milling method. The morphology and structure of the superfine RDX/Al composite were characterized by scanning electron microscopy (SEM) and X-ray photoelectron spectroscopy (XPS). The thermal decomposition properties were analyzed by thermogravimetric analysis (TGA), differential scanning calorimetry (DSC), and thermal-infrared spectrometry (DSC-FTIR) online. The results showed that the as-prepared material was a type of a novel superfine composite with the superfine RDX particles coated on the surface of Al flakes. XPS analysis indicated that a new Al-N bond was formed in the superfine RDX/Al composite and both physical and chemical absorptions existed between RDX and Al at the same time. The thermal decomposition temperature of RDX in the superfine $\mathrm{RDX} / \mathrm{Al}$ composite had a shift of about $50{ }^{\circ} \mathrm{C}$ towards the lower temperature range compared with that of the neat superfine RDX when tested at four heating rates of $5,15,25$ and $35{ }^{\circ} \mathrm{C} \mathrm{min}{ }^{-1}$. Its activation energy value also decreased to $70.8 \mathrm{~kJ} \mathrm{~mol}^{-1}$ compared with that of the neat superfine RDX $\left(119.6 \mathrm{~kJ} \mathrm{~mol}^{-1}\right)$. Moreover, thermal sensitivity of the superfine RDX/Al composite increased. DSC-FTIR analysis showed that the main decomposition products of the superfine RDX/Al composite were $\mathrm{N}_{2} \mathrm{O}$ and $\mathrm{CO}_{2}$ with nearly no $\mathrm{NO}$ and $\mathrm{NO}_{2}$ detected. The formation of $\mathrm{Al}-\mathrm{N}$ bond and reactive $\mathrm{Al}$ atoms are the main reasons for the notably advanced decomposition of RDX in the superfine RDX/Al composite.
\end{abstract}

\section{Introduction}

1,3,5-Trimethylene trinitramine (RDX) is the main energetic ingredient in both explosives and propellants. Its thermal decomposition characteristics directly affect the properties of explosives and propellants. ${ }^{\mathbf{1 - 4}}$ Thus, so far numerous papers have been published on the catalytic decomposition of RDX and many achievements have been made..$^{5-9}$

Aluminum (Al), a type of fuel additive, is widely applied in explosive systems to improve the heat of explosion and power capability owing to its high calorific value and energy density. ${ }^{\mathbf{1 0 - 1 3}}$ It also plays an important role in propellants in seeking higher combustion efficiency and lower pressure exponent for the main fuel. ${ }^{\mathbf{1 4 - 1 6}}$

Since RDX and Al usually exist simultaneously in many explosive and propellant formulations as main components, a large amount of research has been performed to study the

${ }^{a}$ National Special Superfine Powder Engineering Research Center of China, School of Chemical Engineering, Nanjing University of Science and Technology, Nanjing 210094, China. E-mail: superfine_jw@126.com; Fax: +86 25 84315042; Tel: +86 25 84315042

${ }^{b} X i$ 'an Modern Chemistry Research Institute, Xi'an 710065, China performance, thermal behavior and decomposition mechanism of explosives and propellants containing $\mathrm{Al}$ and RDX. ${ }^{17-23} \mathrm{Zhu}$ et al. ${ }^{19}$ studied the influence of different aluminum particle size on the thermal decomposition of RDX and found that $\mathrm{Al}$ with particle size of $40 \mathrm{~nm}$ catalyzed the decomposition of RDX. Fang et $a .^{20}$ prepared different propellants with graded aluminum powders containing superfine aluminum (SAl), and the experimental results indicated that SAl could effectively improve the combustion characteristics of propellants. Ye et al. ${ }^{22}$ adopted generalized gradient approximation of the density functional theory (DFT) to study the adsorption and decomposition mechanism of RDX on the surface of $\mathrm{Al}$ and found that the attractive forces between $\mathrm{Al}$ atoms and $\mathrm{RDX}$ molecules induced breaking of the $\mathrm{N}-\mathrm{O}$ and $\mathrm{N}-\mathrm{N}$ bonds, leading to the decomposition of explosives on the surface of Al. However, the RDX/Al composites used in most of the studies were usually prepared by a simple physical mixing method, in which the reactive $\mathrm{Al}$ atoms were always covered by an $\mathrm{Al}_{2} \mathrm{O}_{3}$ layer that would decrease the contact between $\mathrm{Al}$ and RDX. Therefore, the analyses of the effect of $\mathrm{Al}$ on the decomposition properties of RDX will not be quite accurate.

In this study, a type of superfine RDX/Al composite energetic material (u-RDX/Al composite) was prepared by a mechanical 
ball-milling method. In order to explore the catalytic effect of $\mathrm{Al}$ on the decomposition of $\mathrm{RDX}$ in the as-prepared u-RDX/Al composite, a series of tests were performed. The morphology and structure of the $\mathrm{u}-\mathrm{RDX} / \mathrm{Al}$ composite were analyzed by SEM and XPS. The thermal characteristics of the u-RDX/Al composite were explored by TG and DSC analyses, while the decomposition mechanism was further studied using a DSC-FTIR coupling method. Furthermore, physical mixtures of superfine RDX and $15 \mu \mathrm{m} \mathrm{Al}$ (u-RDX/m-Al mixture) and mixture of superfine RDX and superfine $\mathrm{Al}$ (u-RDX/u-Al mixture) were prepared and characterized for comparison with the $\mathrm{u}-\mathrm{RDX} / \mathrm{Al}$ composite.

\section{Experimental}

\subsection{Materials}

The materials used in this study were $1 \mu \mathrm{m}$ RDX (u-RDX), which was prepared in our laboratory from raw RDX (Gansu Yinguang Chemical Co., Ltd., China), ${ }^{24}$ and $15 \mu \mathrm{m}$ aluminum powders (mAl) (Shanxi North Xing'an Chemical Industry Co., Ltd., China). The mass ratio of $\mathrm{u}-\mathrm{RDX}$ and $\mathrm{Al}$ was constant, i.e., 70/30, as used in many reported studies. ${ }^{\mathbf{1 2 , 1 3 , 2 2}}$

\subsection{Preparation of $\mathrm{u}-\mathrm{RDX} / \mathrm{m}-\mathrm{Al}$ mixture}

To improve the dispersity and uniformity of the $\mathrm{u}-\mathrm{RDX} / \mathrm{m}-\mathrm{Al}$ mixture, a wet mixing technique was applied. First, $14 \mathrm{~g}$ uRDX was added into a container with a small amount of ether and stirred for $30 \mathrm{~min}$ under ultrasonication. Second, $6 \mathrm{~g} \mathrm{~m}-\mathrm{Al}$ was gradually added into the container. After stirring for another $30 \mathrm{~min}$, the container was transferred to a vacuum drying oven and dried at $50{ }^{\circ} \mathrm{C}$ for $2 \mathrm{~h}$. Finally, the dried sample was ground in a polished carnelian mortar for $15 \mathrm{~min}$ and then, the $\mathrm{u}-\mathrm{RDX} / \mathrm{m}-\mathrm{Al}$ mixture was prepared.

\subsection{Preparation of $\mathrm{u}$-RDX/Al composite energetic material}

In order to obtain a new type of composite material rather than a simple mixture of $\mathrm{u}-\mathrm{RDX}$ and $\mathrm{Al}$, the mechanical ball-milling technique, which could provide a powerful force to refine $\mathrm{m}$ $\mathrm{Al}$ and generate the u-RDX/Al composite, was applied. First, 2 $\mathrm{kg}$ of $0.3 \mathrm{~mm} \mathrm{ZrO}_{2}$ was added as the milling medium in the cavity of a vertical ball mill. Then, $6 \mathrm{~g} \mathrm{~m}$-Al powder was added together with $350 \mathrm{~mL}$ of ethyl acetate. Milling rate was set at $1100 \mathrm{rpm}$ and maintained for $30 \mathrm{~min}$. Second, $14 \mathrm{~g}$ of $\mathrm{u}-\mathrm{RDX}$ particles were added into the mill. The milling rate was raised to $1300 \mathrm{rpm}$ and maintained for about $10 \mathrm{~h}$. Finally, the slurry and the milling media were poured out of the cavity and then filtrated to separate the $\mathrm{u}-\mathrm{RDX} / \mathrm{Al}$ composite slurry. The product was dried by vacuum freeze drying technology, as a result of which the u-RDX/Al composite sample was obtained.

\subsection{Preparation of $\mathrm{u}-\mathrm{RDX} / \mathrm{u}-\mathrm{Al}$ mixture}

The mixture of $\mathrm{u}-\mathrm{RDX}$ and superfine $\mathrm{Al}(\mathrm{u}-\mathrm{Al})$ was also prepared to make a comparison with the $\mathrm{u}-\mathrm{RDX} / \mathrm{m}-\mathrm{Al}$ mixture and the $\mathrm{u}$ RDX/Al composite. u-Al was fabricated through a method similar to that mentioned in section 2.3 . First, $2 \mathrm{~kg}$ of $0.3 \mathrm{~mm}$ $\mathrm{ZrO}_{2}, 10 \mathrm{~g} \mathrm{~m}$-Al powders and $350 \mathrm{~mL}$ of ethyl acetate were added in the cavity of a vertical ball mill. The milling rate was set at
$1100 \mathrm{rpm}$ and maintained for about $5 \mathrm{~h}$. Following this, the slurry and milling media were poured out of the cavity and then filtrated to separate the u-Al slurry. The u-Al content in the asprepared slurry was then tested by solvent-evaporation method and the corresponding weight of u-RDX was confirmed based on the mass ratio of u-RDX and $\mathrm{Al}$ (70/30). Then, the u-RDX powder was added to the u-Al slurry and the mixture system was stirred at $500 \mathrm{rpm}$ for $2 \mathrm{~h}$. Finally, the u$\mathrm{RDX} / \mathrm{u}-\mathrm{Al}$ mixture was dried by vacuum freeze drying technology.

\subsection{Equipment and conditions}

The size and morphology of the samples were characterized by a field emission scanning electron microscope (FE-SEM, Hitachi S-4800 II, Japan) operating between 2-10 kV.

The structures of samples were characterized by an ESCALAB 250Xi X-ray photoelectron spectrometer (XPS, Thermo Fisher Scientific, UK) with a monochromatic Al $\mathrm{K} \alpha$ radiation source (energy $1486.68 \mathrm{eV}$ ) at $164 \mathrm{~W}(10.8 \mathrm{~mA}$ and $15.2 \mathrm{kV})$ and a spot size of approximately $0.5 \mathrm{~mm}$ in diameter. During the analysis, vacuum was maintained $<2 \times 10^{-9}$ mbar. The electron energy analyser was operated with a pass energy of $20 \mathrm{eV}$, enabling high resolution of the obtained spectra. A step size of $0.05 \mathrm{eV}$ was employed and each peak was scanned twice.

Thermogravimetric analysis (TG) and differential scanning calorimetric (DSC) experiments were performed using a SDT Q600 thermal analyzer (TA Instruments Co., Ltd., America). The weight of each of the samples was about $1 \mathrm{mg}$ and the samples were placed in an alumina crucible. All the tests were performed under different heating rates of $5,15,25$ and $35{ }^{\circ} \mathrm{C} \mathrm{min}{ }^{-1}$ from 50 to $400{ }^{\circ} \mathrm{C}$ with high-purity nitrogen flowing at a rate of 50 $\mathrm{mL} \min ^{-1}$.

The DSC-FTIR tests for the $\mathrm{u}-\mathrm{RDX} / \mathrm{Al}$ composite, $\mathrm{u}-\mathrm{RDX} / \mathrm{m}-\mathrm{Al}$ mixture and $\mathrm{u}-\mathrm{RDX} / \mathrm{u}-\mathrm{Al}$ mixture were performed on a Netzsch STA449C (Germany) and Nicolet 5700 FTIR (America) coupling system. The sample $(1.0 \mathrm{mg})$ was placed in an open aluminum crucible with heated at a rate of $20{ }^{\circ} \mathrm{C} \mathrm{min}^{-1}$. High-purity argon

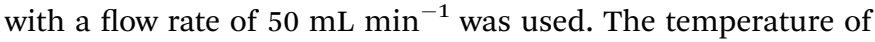
the gas cell and the gas tube between the DSC and FTIR was maintained at $200{ }^{\circ} \mathrm{C}$.

\section{Results and discussion}

The morphology and particle sizes of $\mathrm{m}-\mathrm{Al}$, the $\mathrm{u}-\mathrm{RDX} / \mathrm{m}-\mathrm{Al}$ mixture, the $\mathrm{u}-\mathrm{RDX} / \mathrm{u}-\mathrm{Al}$ mixture and the $\mathrm{u}-\mathrm{RDX} / \mathrm{Al}$ composite were characterized by SEM, and the results are shown in Fig. 1.

As can be seen clearly from Fig. 1a, the size of raw micro aluminum particles was in the range from $5 \mu \mathrm{m}$ to $20 \mu \mathrm{m}$, and their shapes were spherical-like with the surface covered by a rough $\mathrm{Al}_{2} \mathrm{O}_{3}$ layer. Fig. 1b shows that the surface of $\mathrm{m}-\mathrm{Al}$ is coated by superfine RDX particles, but there are still many superfine RDX particles scattered around the mixture. Fig. 1c represents the SEM picture of the as-prepared $\mathrm{u}-\mathrm{RDX} / \mathrm{u}-\mathrm{Al}$ mixture, which shows that the raw micro Al particles transformed into flake-like $\mathrm{Al}$ because of the good ductility of metallic $\mathrm{Al}$, and the surface of the $\mathrm{Al}$ flakes was covered with $\mathrm{u}$ - 


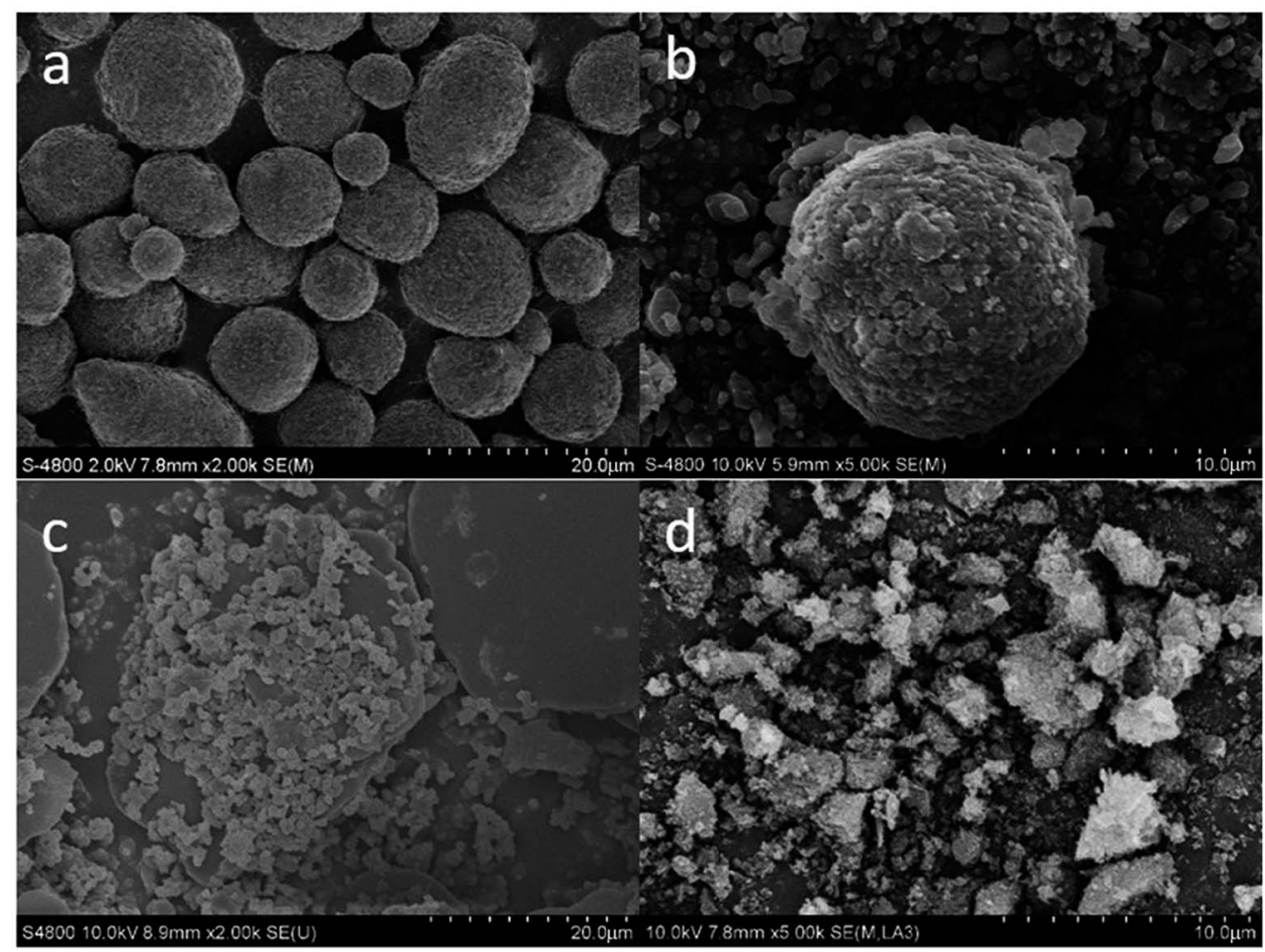

Fig. 1 SEM images of (a) m-Al, (b) u-RDX/m-Al mixture, (c) u-RDX/u-Al mixture and (d) u-RDX/Al composite.

RDX particles. The reactive $\mathrm{Al}$ was exposed and had good contact with u-RDX. As we can see from Fig. 1d, the u-RDX/Al composite has a different structure and shape superfine RDX and $\mathrm{Al}$ particles coexist in the milling system. The size of the flake-like Al particles decreased further due to the role of superfine RDX particles that act as a type of milling aid in the milling system. Furthermore, the granularity of the $1 \mu \mathrm{m} \mathrm{RDX}$ particles also decreased to a submicron scale. In fact, the superfine RDX particles were continuously embedded on the surface of Al flakes, thus forming an irregular layered structure under the powerful impact, friction, and shear forces provided by the mechanical ball-milling method. Hence, this method ensures that the $\mathrm{Al}$ atoms could have full contact with the RDX molecules in contrast to the $\mathrm{u}-\mathrm{RDX} / \mathrm{m}-\mathrm{Al}$ mixture and $\mathrm{u}-\mathrm{RDX} / \mathrm{u}-$ Al mixture.

The structures of $\mathrm{u}-\mathrm{RDX} / \mathrm{m}-\mathrm{Al}$ mixture, $\mathrm{u}-\mathrm{RDX} / \mathrm{u}-\mathrm{Al}$ mixture and $\mathrm{u}-\mathrm{RDX} / \mathrm{Al}$ composite were analysed by XPS; the resulting $\mathrm{Al}$ $2 \mathrm{p}$ and $\mathrm{N} 1 \mathrm{~s}$ XPS spectra of the three samples are presented in Fig. 2. In addition, the corresponding XPS peak values at different peak positions are listed in Table 1.

As shown in Fig. 2a, Al has two XPS peaks in the spectrum of the $\mathrm{u}-\mathrm{RDX} / \mathrm{m}-\mathrm{Al}$ mixture. The peak at $74.1 \mathrm{eV}$ corresponds to the $\mathrm{Al}-\mathrm{O}$ bond of $\mathrm{Al}_{2} \mathrm{O}_{3}$, which was produced by the oxidation of pure Al. The peak at $71.8 \mathrm{eV}$ corresponds to the $\mathrm{Al}-\mathrm{Al}$ bond of pure $\mathrm{Al}$ in micro aluminum. Similarly, the $\mathrm{N} 1 \mathrm{~s}$ spectrum also has two peaks at $407.1 \mathrm{eV}$ and $401.4 \mathrm{eV}$, corresponding to $\mathrm{N}$ of $-\mathrm{NO}_{2}$ and $\mathrm{C}-\mathrm{N}-\mathrm{C}$ in the superfine $\mathrm{RDX}$. These results indicated that there was no chemical bond between superfine RDX and micro $\mathrm{Al}$ particles in the as-prepared $\mathrm{u}-\mathrm{RDX} / \mathrm{m}$-Al mixture. The same curves could be observed in Fig. $2 \mathrm{c}$ and $\mathrm{d}$ revealing that the newly prepared $\mathrm{u}-\mathrm{Al}$ also did not chemically adsorb the u$\mathrm{RDX}$ despite the reactive $\mathrm{Al}$ atoms having full physical contact with RDX molecules.

However, there were apparent distinctions between the XPS spectra of u-RDX/Al composite (Fig. 2e and f) and that of either $\mathrm{u}-\mathrm{RDX} / \mathrm{m}-\mathrm{Al}$ mixture (Fig. 2a and b) or u-RDX/u-Al mixture (Fig. $2 \mathrm{c}$ and d). It can be clearly observed that the $\mathrm{Al} 2 \mathrm{p}$ and $\mathrm{N} 1 \mathrm{~s}$ peaks of the $\mathrm{u}-\mathrm{RDX} / \mathrm{Al}$ composite are divided into three peaks. The extra peak at $73.5 \mathrm{eV}$ in the $\mathrm{Al} 2 \mathrm{p}$ spectrum could be ascribed to the Al-N bond (Fig. 2e), and the peak at $399.6 \mathrm{eV}$ in the $\mathrm{N}$ 1s spectrum is assigned to $\mathrm{N}-\mathrm{Al}$ bond (Fig. 2f). These results indicate that the Al-N bond exists in the $\mathrm{u}-\mathrm{RDX} / \mathrm{Al}$ composite and formed by the combination of $\mathrm{N}$ in RDX and Al under the strong mechanical milling force. Thus, it can be concluded that there exist physical absorption and chemical absorption simultaneously in the as-prepared $\mathrm{u}-\mathrm{RDX} / \mathrm{Al}$ composite; this result was consistent with the findings reported by Ye et al. in ref. 22 .

The analyses of thermodynamics parameters would be beneficial for the better understanding of the thermolysis properties of the energetic materials. In this study, the thermal properties of neat $\mathrm{u}-\mathrm{RDX}, \mathrm{u}-\mathrm{RDX} / \mathrm{m}-\mathrm{Al}$ mixture, u-RDX/u-Al mixture and $\mathrm{u}-\mathrm{RDX} / \mathrm{Al}$ composite were analyzed by TG-DSC measurements. The TG curves of neat $\mathrm{u}-\mathrm{RDX}, \mathrm{u}-\mathrm{RDX} / \mathrm{m}-\mathrm{Al}$ mixture, $\mathrm{u}-\mathrm{RDX} / \mathrm{u}-\mathrm{Al}$ mixture and $\mathrm{u}-\mathrm{RDX} / \mathrm{Al}$ composite at a heating rate of $35{ }^{\circ} \mathrm{C} \mathrm{min}{ }^{-1}$ are shown in Fig. 3, and the DSC traces of these samples at the heating rate of 5, 15, 25 and $35{ }^{\circ} \mathrm{C} \min ^{-1}$ are shown in Fig. 4 .

It can be observed from Fig. 3 that the TG curve of the u-RDX/ $\mathrm{m}$-Al mixture is similar to that of neat $\mathrm{u}-\mathrm{RDX}$, and they suffered 

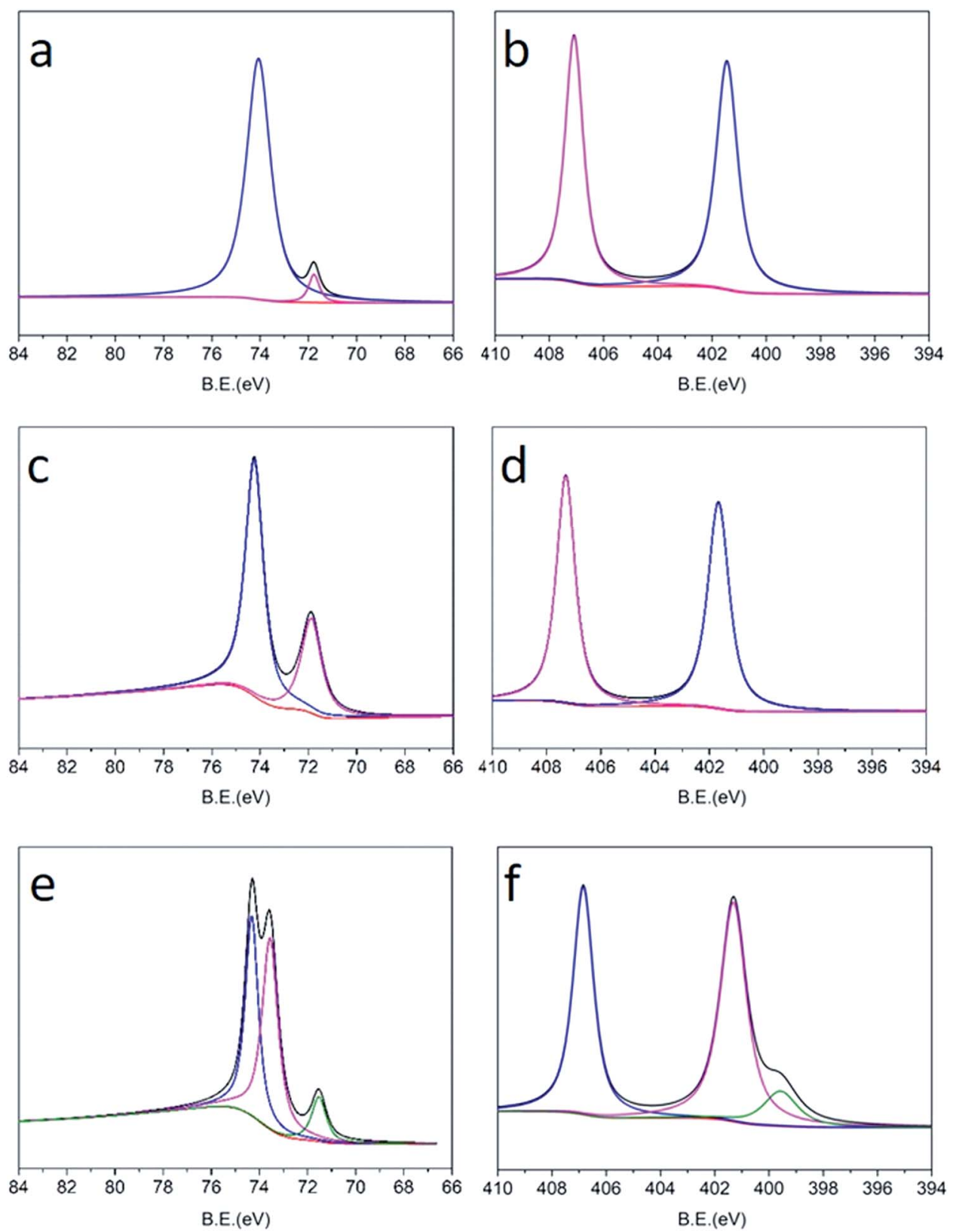

Fig. 2 XPS spectra of (a) Al 2p and (b) N 1s of the $u-R D X / m-A l$ mixture, (c) Al 2p and (d) N 1s of the $u$-RDX/u-Al mixture, and (e) Al 2p and (f) N 1s of the $u$-RDX/Al composite.

Table 1 XPS peak values of $A I 2 p$ and $N$ 1s of $u-R D X / m-A l$ mixture, $u$ RDX/U-Al mixture and $u-R D X / A l$ composite

\begin{tabular}{lllllllll}
\hline & \multicolumn{2}{l}{$\mathrm{Al} 2 \mathrm{p}(\mathrm{eV})$} & & & $\mathrm{N} 1 \mathrm{~s}(\mathrm{eV})$ & \\
\cline { 2 - 3 } \cline { 7 - 8 } Samples & $\mathrm{Al}-\mathrm{O}$ & $\mathrm{Al}-\mathrm{N}$ & $\mathrm{Al}-\mathrm{Al}$ & & $-\mathrm{NO}_{2}$ & $\mathrm{C}-\mathrm{N}-\mathrm{C}$ & $\mathrm{N}-\mathrm{Al}$ \\
\hline u-RDX/m-Al mixture & 74.1 & - & 71.8 & & 407.1 & 401.4 & - \\
u-RDX/u-Al mixture & 74.2 & - & 71.9 & & 407.3 & 401.7 & - \\
u-RDX/Al composite & 74.3 & 73.5 & 71.5 & & 406.8 & 401.3 & 399.6
\end{tabular}

a large mass loss from 225 to $270{ }^{\circ} \mathrm{C}$, indicating that $\mathrm{m}-\mathrm{Al}$ had negligible effect on the decomposition of RDX. However, the TG curves of $\mathrm{u}-\mathrm{RDX} / \mathrm{u}-\mathrm{Al}$ mixture and $\mathrm{u}-\mathrm{RDX} / \mathrm{Al}$ composite exhibit different traces. It is apparent that the onset and final temperatures of weight loss in the $\mathrm{u}-\mathrm{RDX} / \mathrm{u}-\mathrm{Al}$ mixture and $\mathrm{u}-\mathrm{RDX} / \mathrm{Al}$ composite were lowered. As the temperature increased, the $\mathrm{u}$ $\mathrm{RDX} / \mathrm{u}-\mathrm{Al}$ mixture exhibited a mass loss process from 210 to $250{ }^{\circ} \mathrm{C}$, while the mass of $\mathrm{u}-\mathrm{RDX} / \mathrm{Al}$ composite reduced in the range of 150 to $220^{\circ} \mathrm{C}$. Moreover, due to the release of absorbed gases or moisture from the surface of the u-RDX/Al composite, the mass of $\mathrm{u}-\mathrm{RDX} / \mathrm{Al}$ composite decreased slowly at the initial stage of weight loss. ${ }^{25,26}$ After the completion of the reaction, the mass percentages of the $\mathrm{u}-\mathrm{RDX} / \mathrm{u}-\mathrm{Al}$ mixture and the $\mathrm{u}-\mathrm{RDX} / \mathrm{Al}$ composite were about $35 \%$ and $40 \%$ at $350{ }^{\circ} \mathrm{C}$, respectively, which were $30 \%$ higher than the corresponding mass percentage of $\mathrm{Al}$ in the $\mathrm{u}-\mathrm{RDX} / \mathrm{m}-\mathrm{Al}$ mixture. This difference was mainly attributed to the reaction of the gas products evolving 


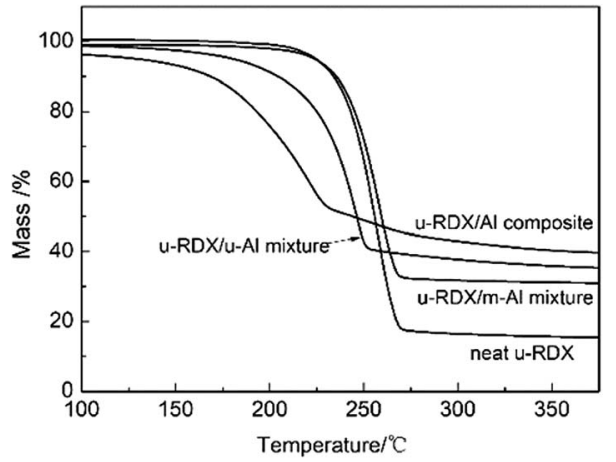

Fig. 3 TG curves of neat $u-R D X, u-R D X / m-A l$ mixture, $u-R D X / u-A l$ mixture and $\mathrm{u}-\mathrm{RDX} / \mathrm{Al}$ composite at the heating rate of $35^{\circ} \mathrm{C} \mathrm{min}^{-1}$.

from the decomposition process of $\mathrm{u}-\mathrm{RDX}$ with the reactive $\mathrm{Al}$ atoms in $\mathrm{u}-\mathrm{Al}$.

Fig. $4 \mathrm{a}$ and $\mathrm{b}$ show the similar curves comprising a melting endotherm followed by exothermic decomposition for neat $\mathrm{u}$ $\mathrm{RDX}$ and $\mathrm{u}-\mathrm{RDX} / \mathrm{m}-\mathrm{Al}$ mixture. It can be found that the exothermic peak temperature $\left(T_{\mathrm{P}}\right)$ of the $\mathrm{u}-\mathrm{RDX} / \mathrm{m}$-Al mixture shifted by about $1-3{ }^{\circ} \mathrm{C}$ towards lower temperature compared with the peak temperatures of neat u-RDX, which could be ascribed to the thermal conductivity of m-Al. The DSC curve of the $\mathrm{u}-\mathrm{RDX} / \mathrm{u}-\mathrm{Al}$ mixture exhibited the same traces as that of $\mathrm{u}-$
$\mathrm{RDX}$ and the $\mathrm{u}-\mathrm{RDX} / \mathrm{m}-\mathrm{Al}$ mixture. However, the $T_{\mathrm{P}}$ of $\mathrm{u}-\mathrm{RDX}$ in the $\mathrm{u}-\mathrm{RDX} / \mathrm{u}-\mathrm{Al}$ mixture had a larger shift of approximately $15{ }^{\circ} \mathrm{C}$ towards the lower temperatures compared with that of neat u-RDX, which was consistent with the TG results. However, there was only an exothermic peak for the u-RDX/Al composite and the melting endotherm did not exist, as evident from Fig. $4 \mathrm{~d}$. The melting process was covered within the exothermic process because of the advancement of reaction onset temperature, which was lower than the melting temperature of RDX. The $T_{\mathrm{P}}$ of RDX in the $\mathrm{u}-\mathrm{RDX} / \mathrm{Al}$ composite was much lower than that of neat $\mathrm{u}-\mathrm{RDX}$ at all the four heating rates with a difference of about $50{ }^{\circ} \mathrm{C}$.

The kinetic parameters for RDX decomposition were calculated according to the exothermic peak temperature dependence as a function of heating rate (Kissinger correlation). ${ }^{27}$ The exothermic peak temperatures at $5,15,25$ and $35^{\circ} \mathrm{C} \mathrm{min}^{-1}$ and the calculated activation energy values $\left(E_{\mathrm{a}}\right)$ of neat $\mathrm{u}-\mathrm{RDX}, \mathrm{u}-$ $\mathrm{RDX} / \mathrm{m}-\mathrm{Al}$ mixture, u-RDX/u-Al mixture and u-RDX/Al composite under different milling times of $3 \mathrm{~h}, 6 \mathrm{~h}$ and $10 \mathrm{~h}$ are tabulated in Table 2 .

$$
\ln \left(\frac{\beta}{T_{\mathrm{P}}^{2}}\right)=-\frac{E_{\mathrm{a}}}{R T_{\mathrm{P}}}+\ln \left(\frac{A R}{E_{\mathrm{a}}}\right)
$$

where $\beta$ is the heating rate in degrees celsius per minute, $T_{\mathrm{P}}$ is the maximum exothermic peak temperature, $R$ is the ideal gas
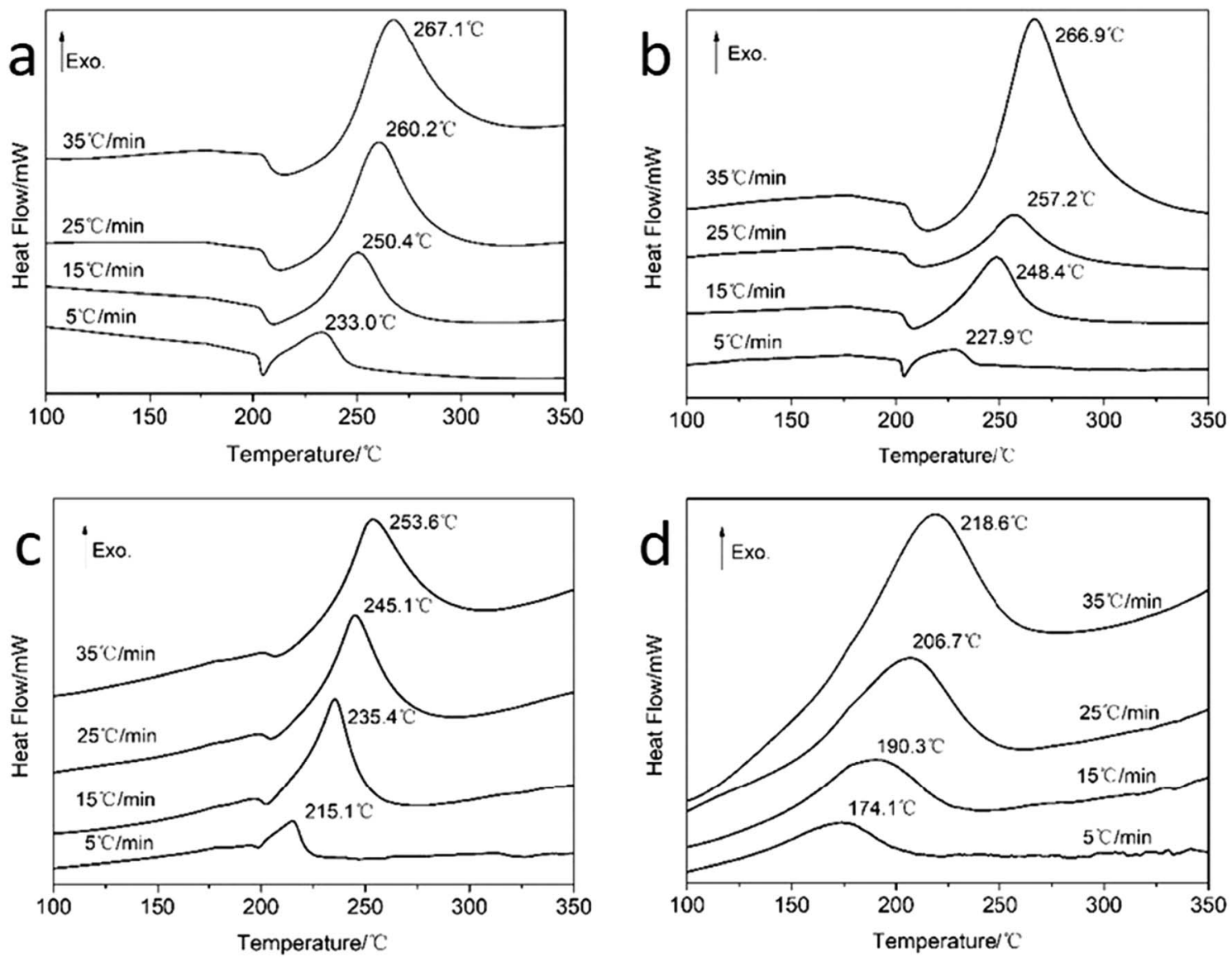

Fig. 4 DSC curves of (a) neat u-RDX, (b) u-RDX/m-Al mixture, (c) u-RDX/u-Al mixture and (d) u-RDX/Al composite at heating rates of 5, 15, 25 and $35^{\circ} \mathrm{C} \mathrm{min}^{-1}$. 
Table 2 DSC peak temperatures and kinetic parameters for neat u-RDX, u-RDX/m-Al mixture, u-RDX/u-Al mixture and u-RDX/Al composite under milling times of $3 \mathrm{~h}, 6 \mathrm{~h}$ and $10 \mathrm{~h}$ at $5,15,25$ and $35^{\circ} \mathrm{C} \mathrm{min}{ }^{-1}$

\begin{tabular}{|c|c|c|c|c|c|c|c|}
\hline \multirow[b]{2}{*}{ Samples } & \multicolumn{4}{|c|}{$T_{\mathrm{P}, \beta}\left({ }^{\circ} \mathrm{C}\right)$} & \multirow[b]{2}{*}{$E_{\mathrm{a}}\left(\mathrm{kJ} \mathrm{mol}^{-1}\right)$} & \multirow[b]{2}{*}{$A\left(\min ^{-1}\right)$} & \multirow[b]{2}{*}{$R^{2}$} \\
\hline & $T_{\mathrm{P}, 5}$ & $T_{\mathrm{P}, 15}$ & $T_{\mathrm{P}, 25}$ & $T_{\mathrm{P}, 35}$ & & & \\
\hline $\mathrm{u}-\mathrm{RDX} / \mathrm{m}-\mathrm{Al}$ mixture & 227.9 & 248.4 & 257.2 & 266.9 & 105.7 & $4.60 \times 10^{8}$ & 0.9951 \\
\hline $\mathrm{u}-\mathrm{RDX} / \mathrm{u}-\mathrm{Al}$ mixture & 215.1 & 235.4 & 245.4 & 253.6 & 100.8 & $2.62 \times 10^{8}$ & 0.9984 \\
\hline $\mathrm{u}-\mathrm{RDX} / \mathrm{Al}$ composite-3 $\mathrm{h}$ & 201.3 & 218.1 & 230.8 & 235.4 & 103.1 & $1.09 \times 10^{9}$ & 0.9905 \\
\hline
\end{tabular}

constant, $E_{\mathrm{a}}$ is the activation energy, and $A$ is the preexponential factor.

It can be clearly observed that the $E_{\mathrm{a}}$ value of u-RDX in the uRDX/Al composite decreased to only $70.8 \mathrm{~kJ} \mathrm{~mol}^{-1}$ compared with $119.6 \mathrm{~kJ} \mathrm{~mol}^{-1}$ of neat u-RDX, $105.7 \mathrm{~kJ} \mathrm{~mol}^{-1}$ of the u-RDX/ $\mathrm{m}$-Al mixture, and $100.8 \mathrm{~kJ} \mathrm{~mol}^{-1}$ of the $\mathrm{u}-\mathrm{RDX} / \mathrm{u}-\mathrm{Al}$ mixture. These results showed that $\mathrm{u}-\mathrm{RDX}$ in the as-prepared composite easily decomposed with the increase in temperature.

As can be seen from Table $2, T_{\mathrm{P}}$ and $E_{\mathrm{a}}$ values of the u-RDX/Al composite decreased with the increase in milling time. The decomposition temperature of $\mathrm{u}-\mathrm{RDX}$ in the u-RDX/Al composite with $3 \mathrm{~h}$ of milling time had a significant reduction by $30{ }^{\circ} \mathrm{C}$ compared with that of the neat u-RDX. This difference in temperature increased to $50{ }^{\circ} \mathrm{C}$ when the milling time was extended to $10 \mathrm{~h}$. In other words, the contact between u-RDX molecules and $\mathrm{Al}$ atoms became highly sufficient in the milling system with the increase in milling time, which led to the formation of more $\mathrm{Al}-\mathrm{N}$ bonds. This may be a possible reason for the easy catalytic decomposition of $\mathrm{u}-\mathrm{RDX}$ in the $\mathrm{u}$ RDX/Al composite.

The critical ignition temperature of thermal explosion $\left(T_{\mathrm{b}}\right)$ should be the lowest to ensure safety of an explosive when it is heated without any thermal dissipation. ${ }^{28}$ In this study, the critical temperatures for neat $\mathrm{u}-\mathrm{RDX}, \mathrm{u}-\mathrm{RDX} / \mathrm{m}-\mathrm{Al}$ mixture, $\mathrm{u}$ $\mathrm{RDX} / \mathrm{u}-\mathrm{Al}$ mixture and $\mathrm{u}-\mathrm{RDX} / \mathrm{Al}$ composite were calculated using eqn (2) and (3), ${ }^{29}$ and the results are shown in Table 3.

$$
T_{i}=T_{0}+b \beta_{i}+c \beta_{i}^{2}+d \beta_{i}^{3}(i=1,2,3,4)
$$

where $T_{0}$ is $T_{\mathrm{P}}$ at $\beta \rightarrow 0, b, c$ and $d$ are coefficients, $\beta_{i}$ is the heating rate $\left(\mathrm{K} \mathrm{min}^{-1}\right)$, and $T_{i}$ is the peak temperature at $\beta_{i}$.

$$
T_{\mathrm{b}}=\frac{E_{\mathrm{a}}-\sqrt{E_{\mathrm{a}}{ }^{2}-4 E_{\mathrm{a}} R T_{0}}}{2 R}
$$

Table 3 Critical temperature of thermal explosion for neat $u$-RDX, u$\mathrm{RDX} / \mathrm{m}$-Al mixture, u-RDX/u-Al mixture and u-RDX/Al composite under different milling time of $3 \mathrm{~h}, 6 \mathrm{~h}$ and $10 \mathrm{~h}$

\begin{tabular}{lll}
\hline Samples & $T_{0}\left({ }^{\circ} \mathrm{C}\right)$ & $T_{\mathrm{b}}\left({ }^{\circ} \mathrm{C}\right)$ \\
\hline Neat u-RDX & 219.9 & 223.4 \\
u-RDX/m-Al mixture & 209.3 & 212.8 \\
u-RDX/u-Al mixture & 198.0 & 201.3 \\
u-RDX/Al composite-3 h & 192.7 & 195.8 \\
u-RDX/Al composite-6 h & 173.7 & 176.8 \\
u-RDX/Al composite-10 h & 167.5 & 171.0
\end{tabular}

where $E_{\mathrm{a}}$ is activation energy $\left(\mathrm{J} \mathrm{mol}^{-1}\right)$ and $R$ is the gas constant $\left(8.314 \mathrm{~J} \mathrm{k}^{-1} \mathrm{~mol}^{-1}\right)$.

Table 3 shows that the critical temperatures of neat $\mathrm{u}-\mathrm{RDX}$, $\mathrm{u}-\mathrm{RDX} / \mathrm{m}-\mathrm{Al}$ mixture and $\mathrm{u}-\mathrm{RDX} / \mathrm{u}-\mathrm{Al}$ mixture are $223.4{ }^{\circ} \mathrm{C}$, $212.8^{\circ} \mathrm{C}$ and $201.3{ }^{\circ} \mathrm{C}$, respectively, while the $T_{\mathrm{b}}$ values of the $\mathrm{u}$ $\mathrm{RDX} / \mathrm{Al}$ composite prepared under milling times of $3 \mathrm{~h}, 6 \mathrm{~h}$ and $10 \mathrm{~h}$ were much lower (about $195.8{ }^{\circ} \mathrm{C}, 176.8^{\circ} \mathrm{C}$ and $171.0^{\circ} \mathrm{C}$, respectively). These results indicated that the thermal sensitivity of $\mathrm{u}-\mathrm{RDX}$ increased with the addition of $\mathrm{Al}$ and the increase in degree of sensitivity was even greater on adopting mechanical ball-milling method and extending the milling time compared with that of physical blending.

DSC-FTIR analyses were conducted to research the decomposition mechanisms of $\mathrm{u}-\mathrm{RDX} / \mathrm{m}-\mathrm{Al}$ mixture, u-RDX/u-Al mixture and $\mathrm{u}-\mathrm{RDX} / \mathrm{Al}$ composite. The FTIR results are shown in Fig. 5. The total absorbance of gaseous products in $\mathrm{u}-\mathrm{RDX} / \mathrm{m}$ Al mixture, u-RDX/u-Al mixture and u-RDX/Al composite are presented in Fig. 5a, c and e, respectively. Five different points were chosen from the curves in Fig. $5 \mathrm{a}$, $\mathrm{c}$ and e, and the corresponding FTIR spectra of the gas products are shown in Fig. 5b, $\mathrm{d}$ and $\mathrm{f}$.

According to these spectra, the main gas products for the $\mathrm{u}$ $\mathrm{RDX} / \mathrm{m}$-Al mixture were $\mathrm{N}_{2} \mathrm{O}, \mathrm{CO}_{2}$ and $\mathrm{NO}_{2}$ besides a few $\mathrm{NO}$ and $\mathrm{H}_{2} \mathrm{O}$ molecules. Fig. 5d shows that the main gas products evolved from the u-RDX/u-Al mixture are $\mathrm{N}_{2} \mathrm{O}$ and $\mathrm{CO}_{2}$. The amount of $\mathrm{NO}$ and $\mathrm{NO}_{2}$ molecules decreased compared with that from the $\mathrm{u}-\mathrm{RDX} / \mathrm{m}-\mathrm{Al}$ mixture. While it can be seen from the spectra in Fig. $5 \mathrm{f}$ that the main gas products for $\mathrm{u}-\mathrm{RDX} / \mathrm{Al}$ composite are $\mathrm{N}_{2} \mathrm{O}$ and $\mathrm{CO}_{2}$, the amount of $\mathrm{NO}$ and $\mathrm{NO}_{2}$ molecules was too low to be detected. It is easy to conclude that $\mathrm{N}_{2} \mathrm{O}$ and $\mathrm{CO}_{2}$ are the main decomposition products evolved from u-RDX/m-Al mixture, u-RDX/u-Al mixture, or u-RDX/Al composite. With the increase in temperature, the decomposition of RDX initiated by the bond cleavage of $\mathrm{N}-\mathrm{NO}_{2}$, which was the weakest bond, due to which the $\cdot \mathrm{NO}_{2}$ radical formed. Then, - $\mathrm{NO}_{2}$ would react with $-\mathrm{C}-$ and $-\mathrm{N}-$ to form $\mathrm{N}_{2} \mathrm{O}$ and $\mathrm{CO}_{2}$. Moreover, $\mathrm{N}_{2} \mathrm{O}$ would be formed rather than $\mathrm{CO}_{2}$ due to the higher electronegativity of $-\mathrm{N}$ - than that of $-\mathrm{C}-.^{30-32}$ Therefore, the signal of $\mathrm{N}_{2} \mathrm{O}$ is much stronger in the FTIR spectra of $\mathrm{u}-\mathrm{RDX} /$ $\mathrm{m}-\mathrm{Al}$ mixture and $\mathrm{u}-\mathrm{RDX} / \mathrm{u}-\mathrm{Al}$ mixture. Furthermore, it can be observed that the ratio of $\mathrm{CO}_{2}$ to $\mathrm{N}_{2} \mathrm{O}$ in the $\mathrm{u}-\mathrm{RDX} / \mathrm{Al}$ composite is larger than that in the $\mathrm{u}-\mathrm{RDX} / \mathrm{m}-\mathrm{Al}$ mixture and the $\mathrm{u}-\mathrm{RDX} / \mathrm{u}-$ $\mathrm{Al}$ mixture, which is mainly due to the formation of the $\mathrm{Al}-\mathrm{N}$ bond that consumes $-\mathrm{N}-$. 

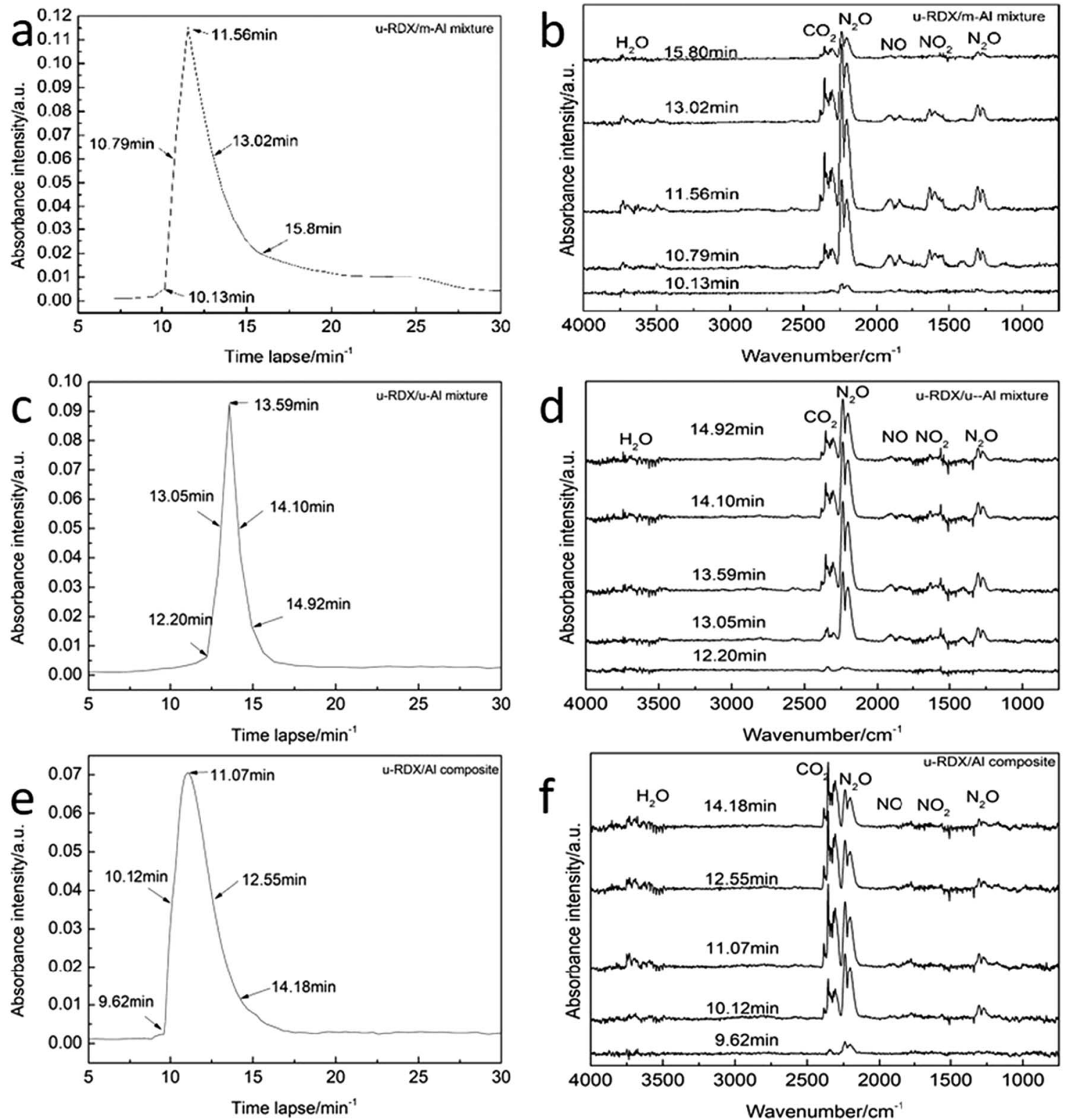

Fig. 5 FTIR spectra of u-RDX/m-Al mixture, u-RDX/u-Al mixture, and u-RDX/Al composite: (a, c and e) total absorbance of gas products; (b, $d$ and f) FTIR spectra of gas products intercepted at different times.

The dependence of absorbance intensity of $\mathrm{N}_{2} \mathrm{O}$ and $\mathrm{NO}_{2}$ from the $\mathrm{u}-\mathrm{RDX} / \mathrm{m}-\mathrm{Al}$ mixture, $\mathrm{u}-\mathrm{RDX} / \mathrm{u}-\mathrm{Al}$ mixture and $\mathrm{u}-\mathrm{RDX} /$ $\mathrm{Al}$ composite on temperature is further depicted in Fig. 6 and 7. There was no significant difference between the onset and peak temperatures corresponding to the detected absorbance intensity of $\mathrm{N}_{2} \mathrm{O}$ and $\mathrm{NO}_{2}$ evolved from the u-RDX/m-Al mixture based on the IR spectra in Fig. 6a and 7a. However, it can be clearly seen that the onset and peak temperatures corresponding to the intensity of $\mathrm{N}_{2} \mathrm{O}$ from the $\mathrm{u}-\mathrm{RDX} / \mathrm{Al}$ composite (Fig. 6b) and u-RDX/u-Al mixture (Fig. 6c) are distinctly lower than that of $\mathrm{u}-\mathrm{RDX} / \mathrm{m}-\mathrm{Al}$ mixture, indicating that the decomposition of RDX in $\mathrm{u}-\mathrm{RDX} / \mathrm{u}-\mathrm{Al}$ mixture and $\mathrm{u}-\mathrm{RDX} / \mathrm{Al}$ composite occurs earlier, corresponding to the findings from TG and DSC analyses. Moreover, the intensity of $\mathrm{NO}_{2}$ from u-RDX/Al composite (Fig. 7b) and u-RDX/u-Al mixture (Fig. 7c) was nearly zero during the decomposition of u-RDX, which indicated that the $\mathrm{O}$ atoms in RDX were possibly caught by some reducing agents that existed in $\mathrm{u}-\mathrm{RDX} / \mathrm{u}-\mathrm{Al}$ mixture and $\mathrm{u}-\mathrm{RDX} /$ $\mathrm{Al}$ composite rather than the $\mathrm{u}-\mathrm{RDX} / \mathrm{m}-\mathrm{Al}$ mixture.

When we compared the u-RDX/m-Al mixture and $\mathrm{u}-\mathrm{RDX} / \mathrm{u}-\mathrm{Al}$ mixture, we found that the main difference between the two mixtures was the shape of the Al particles. The Al particles in the $\mathrm{u}-\mathrm{RDX} / \mathrm{u}-\mathrm{Al}$ mixture were in the form of flakes that had bigger specific surface area and more reactive $\mathrm{Al}$ atoms on the surface and could have full contact with u-RDX. This difference caused the advanced decomposition of $\mathrm{u}-\mathrm{RDX}$ in the $\mathrm{u}-\mathrm{RDX} / \mathrm{u}-\mathrm{Al}$ mixture and hence, fewer $\mathrm{NO}_{2}$ molecules formed. Thus, it can be concluded that the as-prepared flake-like $\mathrm{Al}$ particles have a catalytic effect on the decomposition of RDX due to its better thermal conductivity and reaction with the decomposition 


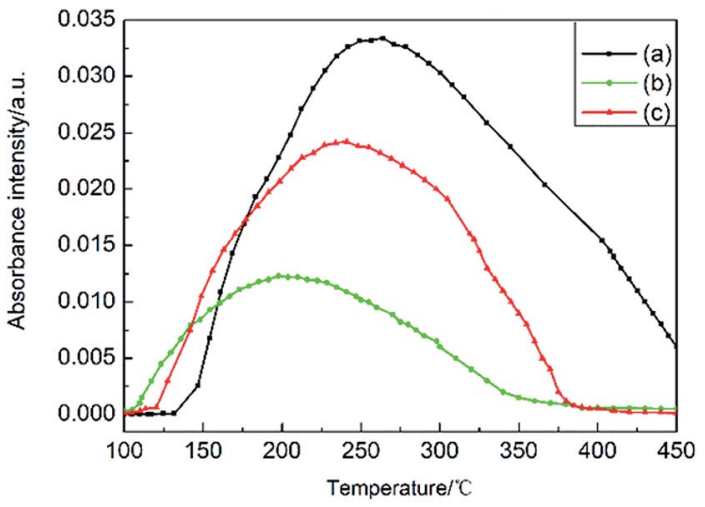

Fig. 6 Temperature dependency of FTIR intensity of $\mathrm{N}_{2} \mathrm{O}$ from (a) u$\mathrm{RDX} / \mathrm{m}$-Al mixture, (b) u-RDX/Al composite, and (c) u-RDX/u-Al mixture.

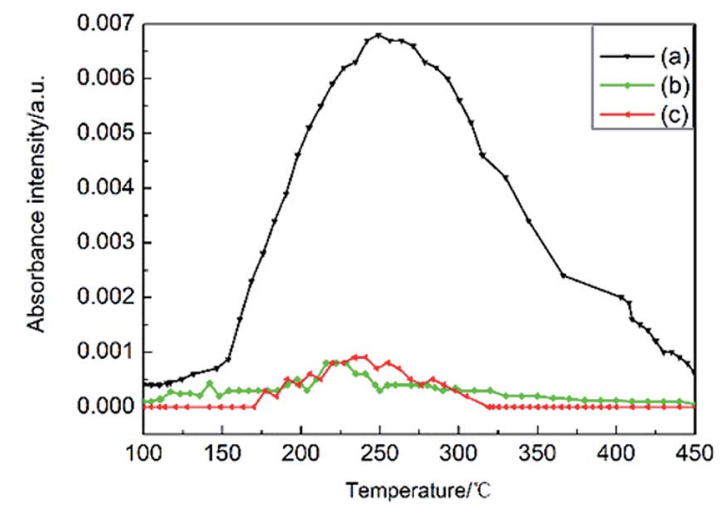

Fig. 7 Dependence of FTIR intensity of $\mathrm{NO}_{2}$ from (a) $u-R D X / m-A l$ mixture, (b) u-RDX/Al composite, and (c) u-RDX/u-Al mixture on temperature.

products during the decomposition of RDX compared with normal m-Al particles.

The main difference between the $\mathrm{u}-\mathrm{RDX} / \mathrm{u}-\mathrm{Al}$ mixture and the $\mathrm{u}-\mathrm{RDX} / \mathrm{Al}$ composite is that a new Al-N bond was formed in the $\mathrm{u}-\mathrm{RDX} / \mathrm{Al}$ composite due to the mechanical ball milling method. This resulted in the decomposition of $\mathrm{u}-\mathrm{RDX}$ in the $\mathrm{u}-\mathrm{RDX} / \mathrm{Al}$ composite at a greatly advanced temperature range. Thus, it can be concluded that the $\mathrm{Al}-\mathrm{N}$ bond plays an important role in the decomposition of u-RDX. Moreover, it can be inferred that the Al-N bond may dominate the decomposition of $\mathrm{u}-\mathrm{RDX}$ than the flake-like Al particles based on the findings from DSC analyses. Furthermore, it is evident that the catalytic decomposition of RDX in the $\mathrm{u}-\mathrm{RDX} / \mathrm{Al}$ composite improved with the increase in milling time because of the formation of more $\mathrm{Al}-\mathrm{N}$ bonds, more reactive $\mathrm{Al}$, and improvement in the thermal conductivity of Al.

Overall, the decomposition mechanisms of RDX in the uRDX/Al composite prepared by mechanical ball milling method are likely dependent on the formation of Al-N bonds and reactive Al. The strong Al-N bond led to weakening of the $\mathrm{N}-\mathrm{N}$ bond and $\mathrm{N}-\mathrm{O}$ bond, which split more easily and promoted the decomposition of $\mathrm{u}$-RDX. ${ }^{17}$ Furthermore, more reactive $\mathrm{Al}$ atoms in the Al particles exposed during the milling process. The redox reaction between the fuel (reactive $\mathrm{Al}$ atoms) and the oxidizer (the decomposition products) would proceed, which accelerated the decomposition of u-RDX. Furthermore, the thermal conductivity was likely non-negligible. The smaller the particle size, the better the thermal conductivity. During the milling process, the size of the $\mathrm{Al}$ particles was decreased and hence, the thermal conductivity increased, leading to faster endothermic process with the increase in temperature so that the $\mathrm{u}$-RDX particles would decompose much ahead of the other materials tested in this study.

\section{Conclusions}

(1) A superfine RDX/Al composite energetic material was successfully prepared by the mechanical ball-milling method, in which both physical absorption and chemical absorption exist between u-RDX and Al.

(2) From the u-RDX/m-Al mixture, the main decomposition products were $\mathrm{N}_{2} \mathrm{O}, \mathrm{CO}_{2}$ and $\mathrm{NO}_{2}$, while from the u-RDX/u-Al mixture and $\mathrm{u}-\mathrm{RDX} / \mathrm{Al}$ composite, the main products were $\mathrm{N}_{2} \mathrm{O}$ and $\mathrm{CO}_{2}$ with almost no $\mathrm{NO}_{2}$.

(3) A series of analyses revealed that the advanced decomposition of $\mathrm{u}-\mathrm{RDX}$ in the $\mathrm{u}-\mathrm{RDX} / \mathrm{Al}$ composite occurred due to the reactive $\mathrm{Al}$ and the $\mathrm{Al}-\mathrm{N}$ bonds, which played a leading role. The degree of decrease in the decomposition temperature was more notable with the increase in milling time. This indicated that the exothermic decomposition properties of $\mathrm{u}$-RDX could be controlled by the adjustment of $\mathrm{Al}$ content and the mechanical ball-milling process. This study will be beneficial for obtaining new formula designs and potential applications for the $\mathrm{RDX} / \mathrm{Al}$ composite.

\section{Conflicts of interest}

There are no conflicts to declare.

\section{Acknowledgements}

This study was financially supported by National Natural Science Foundation of China (No. 51606102, No. 21805139), the Fundamental Research Funds for the Central Universities (No. 30918011312), Basic Product Innovation Technology Research Project of Explosives and Youth Scientific and Technological Innovation Project (QKCZ201713).

\section{Notes and references}

1 K. K. Kuo, G. A. Risha and B. J. Evans, MRS Proc., 2003, 800. 2 W. H. Hsieh and W. Y. Li, Propellants, Explos., Pyrotech., 2015, 23, 128-136.

3 G. T. Sutherland, L. J. Brousard and J. F. Leahy, J. Energ. Mater., 2004, 22, 181-197.

4 D. M. Badujar, M. B. Talawar, S. N. Asthana and P. P. Mahulikar, J. Hazard. Mater., 2008, 151, 289-305.

5 Y. P. Tong, Y. P. Wang, Z. X. Yu, X. Wang, X. J. Yang and L. D. Lu, Mater. Lett., 2008, 62, 889-891. 
6 T. X. Liu, B. X. Li, Y. G. Hao and Z. Y. Yao, Chem. Eng. J., 2014, 244, 382-390.

7 P. Ujwol, K. Henning, N. Rodrigo, A. Sahar, J. Vladislav, M. Philipp, A. Hasan, S. Alberto, S. Helmut and K. Dietmar, Nano Energy, 2014, 6, 167-172.

8 T. Wei, Y. Zhang and K. Xu, RSC Adv., 2015, 5, 70323-70328. 9 Y. Zhang, T. Wei and K. Xu, RSC Adv., 2015, 5, 75630-75635. 10 M. A. Cook, A. S. Filler and R. T. Keyes, J. Phys. Chem., 1957, 61, 189-196.

11 H. Hui, H. H. Jian and H. Yong, Explos. Shock Waves, 2006, 26, 7-11.

12 N. Muravyev, Y. Frolov and A. Pivkina, Propellants, Explos., Pyrotech., 2010, 35, 226-232.

13 P. Langen and P. Barth, Propellants, Explos., Pyrotech., 1979, 4, 129-131.

14 K. Jayaraman, K. V. Anand and D. S. Bhatt, J. Propul. Power, 2009, 25, 471-481.

15 F. Tepper and G. V. Ivanov, Int. J. Energ. Mater. Chem. Propuls., 1997, 4, 636-645.

16 M. C. J. Van Ramshorst, G. L. D. Benedetto and W. Duvalois, Propellants, Explos., Pyrotech., 2016, 41, 700-708.

17 N. Umezawa, R. K. Kalia and A. Nakano, J. Chem. Phys., 2007, 126, 234702.

18 L. Liang, J. Y. Wang and J. Dong, J. Explos. Propellants, 2009, 32, 75-78.
19 Y. L. Zhu, H. Huang and H. Ren, J. Energ. Mater., 2013, 31, 178-191.

20 C. Fang and S. Li, Propellants, Explos., Pyrotech., 2002, 27, 3438.

21 C. Weir, M. L. Pantoya and M. A. Daniels, Combust. Flame, 2013, 160, 2279-2281.

22 C. C. Ye, F. Q. Zhao and S. Y. Xu, J. Mol. Model., 2013, 19, 2451-2458.

23 Y. F. Zheng, H. Nan and P. Xi, J. Explos. Mater., 2015, 5, 1317.

24 J. Liu, W. Jiang and F. S. Li, Acta Armamentarii, 2013, 34, 174180.

25 L. G. Guo, W. L. Song and M. L. Hu, Appl. Surf. Sci., 2008, 254, 2413-2417.

26 Z. H. Wang, C. J. Choi and B. K. Kim, Carbon, 2003, 41, 17511758.

27 H. E. Kissinger, Anal. Chem., 1957, 29, 1702-1706.

28 Y. Luo, P. Chen and F. Q. Zhao, Chin. J. Chem., 2010, 22, 1219-1224.

29 T. Zhang, R. Hu and Y. Xie, Thermochim. Acta, 1994, 244, 171-176.

30 C. J. Wu and L. E. Fried, J. Phys. Chem. A, 1997, 101, 86758679.

31 Y. Wang, X. Song and D. Song, J. Hazard. Mater., 2016, 312, 73-83.

32 X. L. Song, Y. Wang and C. W. An, AIP Adv., 2018, 8, 065009. 